\author{
鼻アレルギー患者に対する鼻閉の評価 \\ - Acoustic Rhinometry による検討一 \\ 大木 幹文・吉野由紀子・自井 信郎
}

\title{
Evaluation of Nasal Obstruction in Patients with Perennial Allergic Rhinitis Using Acoustic Rhinometry
}

\author{
Motofumi Ohki, Yukiko Yoshino and Nobuo Usui \\ (Toho University)
}

The evaluation of nasal obstruction is important for the treatment of perennial allergic rhinitis. Although, nasal resistance induced by rhinomanometry is useful, several authors have reported that nasal resistance is not correlated with the sensation of nasal obstruction.

Acoustic rhinometry was introduced by Hilberg et. al. (1989) to assess the geometry of nasal cavity. The method, based on sound reflection analysis provides an estimate of the cross-sectional area of the nasal cavity as a function of the distance from the nostril. Recently, acoustic rhinometry has become popular in our country. The aim of this study was to evaluate changes in the nasal mucosa of patients with perennial allergic rhinitis and in normal subjects and to investigate the benefits of acoustic rhinometry.

Ten normal subjects and 10 patients with perennial allergic rhinitis were measured by acoustic rhinometry before and after administration of a topical decongestant using an acoustic rhinometer (RHIN2100 SRE co. Denmark). Changes in the nasal volume $(0.8-4.0 \mathrm{~cm})(0-7.0 \mathrm{~cm})$ and cross-sectional area (c-notch) were greater in patients than in normal subjects. However, the nasal volume and cross-sectional area in patients with perennial allergic rhinitis were the same as in normal subjects.

These results suggest that the nasal mucosa of patients with perennial allergic rhinitis is more swollen than that of normal subjects. Moreover, measurements of nasal volume and nasal cross-sectional area are able to define the structure of the nasal cavity. These values can be utilized to evaluate baseline values and improvements when medications are administered.

In conclusion, acoustic rhinometry is potentially useful for evaluating nasal physiology, especially in cases of allergic rhinitis.

Key words : nasal obstruction, allergic rhinitis, acoustic rhinometry

はじめに

近年，免疫学の飛躍的な進歩とともに，アレルギー発 症機序が明らかにされつつあり1), 鼻アレルギーの治療 もアレルギー反応の抑制に効果を上げる薬剤が開発され, 特に最近では鼻閉に効果の期待される抗アレルギー剤も
いくつか見られるよらになった，そこで，日常診療にお いては，これらの薬剤が鼻閉にどら効果を上げるかを評 価することが求められる。しかしながら鼻閉は, 自覚症 状である鼻閉感, 鼻呼吸障害, さらには鼻粘膜の腫脹と いった様々な意味をもって扣り, 必ずしも自覚症状と他 
覚的所見が関連しない症例も認められ，鼻閉の改善の評 価はたやすいことではない213)。客観的評価法の一つと して1989年 Hilberg ら4) は Acoustic Rhinometry による 鼻腔の開存性の評価法を報告し，鼻腔内の狭小部の部位 診断が可能であるとした，その後，国内外で本法の有用 性が検討されているが，私たちは鼻腔モデルによる検討

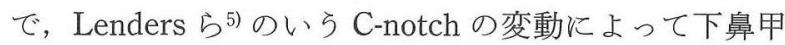
介に批ける粘膜の変化の評価が可能であることを報告し た6). そこで, 今回, Acoustic Rhinometryによって鼻 アレルギー患者と, 鼻症状を伴わないいわゆる正常成人 に和ける鼻粘膜の変化を血管收縮剤投与前後で評価し， 鼻アレルギーの診断, 治療への本法による応用の可能性 について検討した.

\section{対象および方法}

今回対象としたのは，問診拈よび前鼻鏡検査にて耳鼻 咽喉科学的に異常を認めず，さらに鼻症状のない正常成 人 10 名 (正常群) (男性 6 名, 女性 4 名, 年齢19３9歳, 平均 27.8 歳)，拉上び成人通年性鼻アレルギー患者 10 名 (鼻アレルギー群) (男性 3 名, 女性 7 名, 年齢21〜37歳, 平均26.3歳)である. 鼻アレルギーの診断は鼻汁中の好 酸球数, 皮膚反応, 誘発反応のらち 2 つ以上陽性で, か つ免疫学的検査のアラスタット法によりハウスダスト， あるいはダニのスコアが 2 以上であり，アレルギー学会 の基準で中等症以上のものとした ${ }^{7}$. 被検者は，検査の 必要性を十分説明のら光同意を得られた者とした。まず, 15分の安静の後, 鼻腔開存性について Acoustic Rhinometer (RHIN2100，SRE 製) にて前鼻孔からの距離毎の 鼻腔断面積を坐位で測定，さらに局所血管収縮剤である $0.5 \%$ 硝酸ナファゾリン液を定量噴霧器によって両側鼻 腔に $100 \mu 1$ ずつ噴霧し，10分後の鼻腔開存性の変化を 記録した（図 1)。記録は，横軸を鼻腔断面積，縦軸を前 鼻孔からの距離にとり, 断面積と前鼻孔からの距離との 関係を曲線で表した距離一断面積曲線を描き，その特徵 を評価した．この測定曲線には鼻腔断面積の狭小化を示 寸部位が 2 力所認められ Notch を形成する. 前鼻孔よ り 1 番目の Notch する.ささらに血管収縮剤噴霧後の曲線では前鼻孔から 2 番目の C-notch の後緑で曲線のカーブが急激に变化する 部位が認められる。そこで，この部位をChanging Point と定義し CP 点と呼称することとした(図 2)。ま ず,これらの部位の変化に注目して血管収縮剤噴霧前後

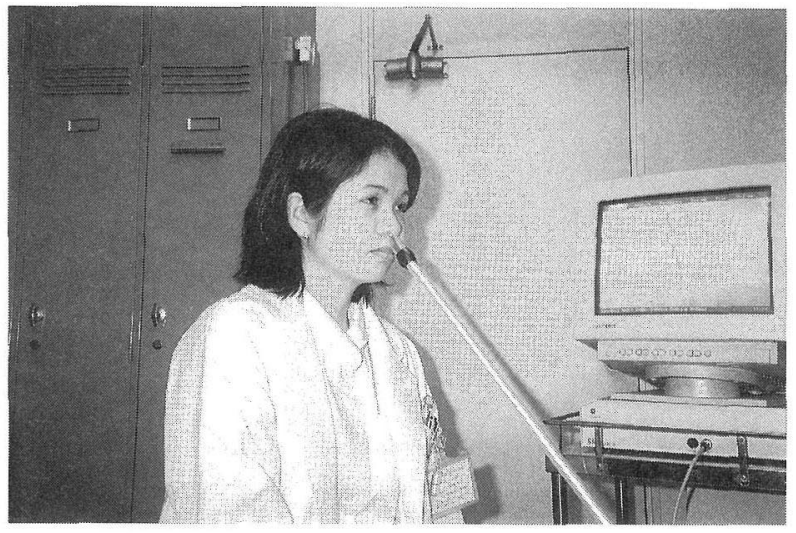

図 1 Acoustic Rhinometryによる鼻腔開存性の測定

による曲線の変化を記録した。

さらに客観的評価の項目として,C-notch における 1) 鼻腔断面積 (C-notch), 和よび 2 ) 鼻腔前方の容積の評価 として前鼻孔からの距離が $0.8 \sim 4.0 \mathrm{~cm}$ までの鼻腔容 積, また 3 ) 鼻腔全体の容積変化の評価として前鼻孔か ら $7.0 \mathrm{~cm}$ をでの鼻腔容積を採用した.

1 ) 測定曲線の変化

まず，正常者と鼻アレルギー患者の血管収縮剂噴霧前 後の測定曲線をみると, 曲線全体の鼻腔開存性の拡大が 認められた(図 2，3），鼻アレルギー患者（図 3 ）は正常 者(図 2 ) に比べて距離毎の鼻腔断面積の变化が大きく, 曲線全体の変化も顕著であった。ささらに, 収縮後の測定 曲線の特徵をみてみると, 前鼻孔から後方に向かって一 様に鼻腔開存性の拡大を認めるわけではなかった。まず， 正常者に扮いても鼻アレルギ一患者に招いても，Cnotchの尖端がなだらかになり，またC-notch の後縁か ら $\mathrm{CP}$ 点に向かって急激な変化を示した。一方, $\mathrm{CP}$ 点 より後方は核济一定の鼻控開存性の拡大を示した。特に， $\mathrm{CP}$ 点に执ける曲線の変化は鼻アレルギー患者が正常者 に比べて強調された形をとった。

さらに CP 点の前鼻孔からの距離を測定し正常群と鼻 アレルギー群とを比較した(表1)。その結果，両群間に 物いて有意差以認められなかった。

2) 鼻粘膜变化の定量的評価

表 2 亿血管収縮剂噴霧前後における正常者と鼻アレル ギー患者の鼻腔開存性を示した，鼻腔断面積 (C-notch) 


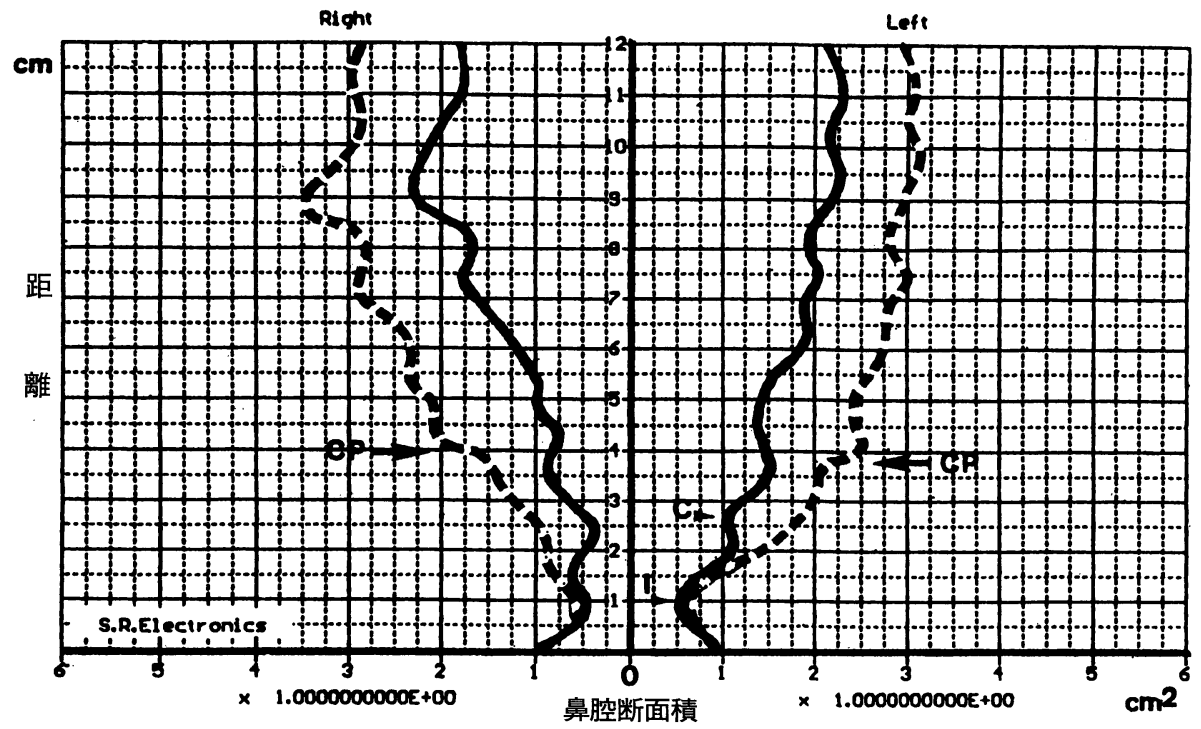

図 2 正常成人例に护ける血管収縮剤噴霧前後の Acoustic Rhinometry の変化 I : I-notch (外側鼻軟骨前端) C : C-notch (下鼻甲介前端) $\mathrm{CP}$ : Changing Point

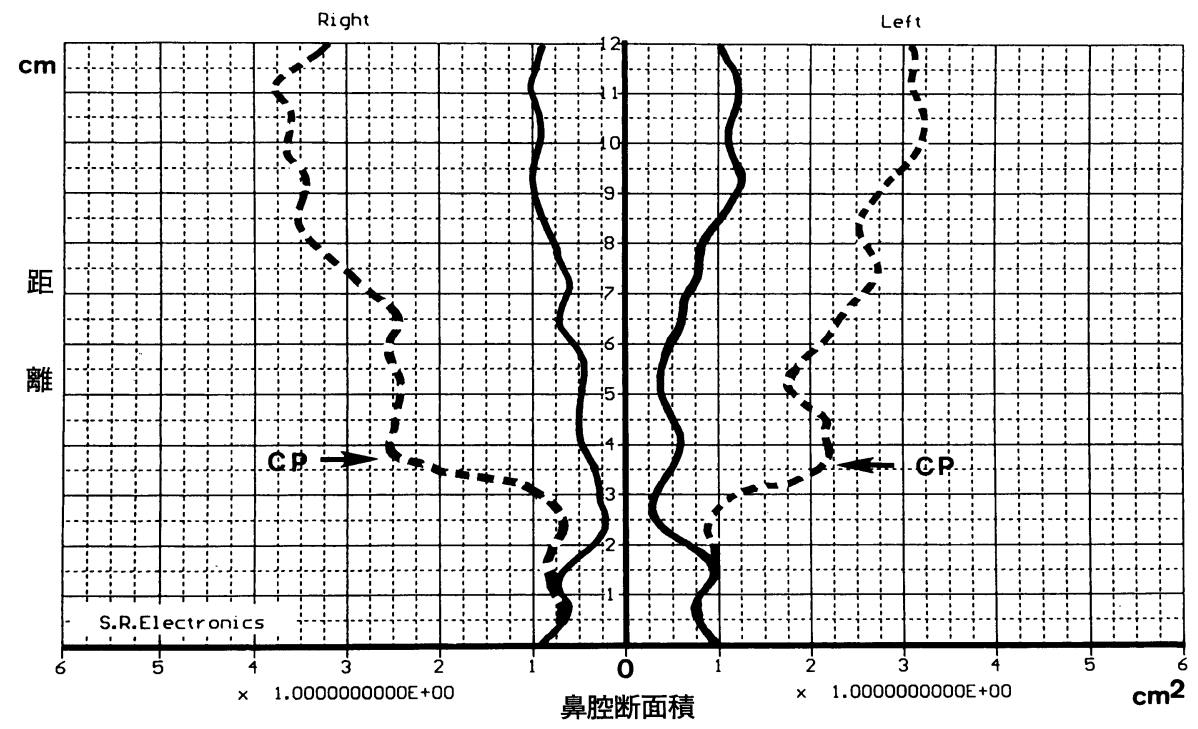

図 3 通年性鼻アレルギー症例に拈ける血管収縮剤噴霧前後の Acoustic Rhinometry の変化

表 1 血管収縮剤噴霧による acoustic rhinomentry 測定曲線の changing point ( $\mathrm{CP}$ 点)

\begin{tabular}{lclc}
\hline \hline & 正常者 & \multicolumn{2}{l}{$\begin{array}{l}\text { 鼻アレルギー } \\
\text { 者 }\end{array}$} \\
\hline 前鼻孔からの距離 & $4.09 \pm 0.18 \mathrm{~cm}$ & $3.89 \pm 0.19 \mathrm{~cm}$ & $\begin{array}{c}\text { N.S. } \\
\text { (t-test) }\end{array}$
\end{tabular}


表 2 血管収縮剤による Acoustic Rhinometry 变化

\begin{tabular}{|c|c|c|c|}
\hline & 正常群 $(\mathrm{N}=10)$ & 鼻アレルギー群 $(\mathrm{N}=10)$ & \\
\hline \multicolumn{4}{|l|}{ 鼻腔断面積 (C-notch) } \\
\hline 血管収縮剤噴霧前 & $0.73 \pm 0.25\left(\mathrm{~cm}^{2}\right)$ & $0.65 \pm 0.18$ & $\mathrm{P}<0.05$ \\
\hline 血管収縮剂噴霧後 & $0.96 \pm 0.31$ & $0.98 \pm 0.30$ & N.S. \\
\hline \multicolumn{4}{|c|}{ 鼻腔容積 $(0.8 \sim 4.0 \mathrm{~cm})$} \\
\hline 血管収縮㶡噴霧前 & $3.14 \pm 0.73\left(\mathrm{~cm}^{3}\right)$ & $2.81 \pm 0.51$ & $\mathrm{P}<0.05$ \\
\hline 血管収縮剂噴霧後 & $4.07 \pm 1.08$ & $4.16 \pm 0.96$ & N.S. \\
\hline \multicolumn{4}{|c|}{ 鼻腔容積 $(0 \sim 7.0 \mathrm{~cm})$} \\
\hline 血管収縮剤噴霧前 & $6.77 \pm 1.66\left(\mathrm{~cm}^{3}\right)$ & $5.72 \pm 0.77$ & $\mathrm{P}<0.05$ \\
\hline \multirow[t]{2}{*}{ 血管収縮斉噴霧後 } & $11.51 \pm 3.02$ & $11.60 \pm 2.13$ & N.S. \\
\hline & & & (t-test) \\
\hline
\end{tabular}

で比較すると，噴霧前では鼻アレルギー患者は正常成人 に比べて有意に狭小化が認められた $(\mathrm{P}<0.05)$. また鼻 腔容積の検討に扣いても，鼻腔容積 $(0.8 \sim 4.0 \mathrm{~cm})$, 鼻 腔容積 $(0 \sim 7.0 \mathrm{~cm})$ ではそれぞれ正常者に比べて鼻アレ ルギー患者に有意の狭小化が認められた $(\mathrm{P}<0.05)$. 一 方, 血管収縮剤である硝酸ナファゾリン局所噴霧後の鼻 腔断面積 (C-notch) は, 正常者と鼻アレルギー患者にお いて，有意の差は認められなかった。同様に, 鼻腔容積 $(0.8 \sim 4.0 \mathrm{~cm})$ の検討でも, 両群間に有意の差は認めら れなかった.さらに鼻腔全体の鼻腔容積 $(0 \sim 7.0 \mathrm{~cm})$ も 血管収縮阂噴霧後には有意差が認められなかった。

3 ）血管収縮剂噴霧前後の鼻粘膜変化率

血管収縮剤噴霧による変化は噴霧前と比較すると, 鼻 アレルギー患者は正常者に比べて鼻粘膜の腫脹が著しか った，そこで, 両者に括ける血管収縮剤噴霧前後の変化 率を検討した(表 3 ). 鼻アレルギー患者の変化率は鼻腔 断面積, 鼻腔容積に拈いて正常者に比べて有意に高かっ

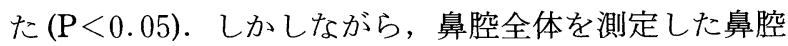
容積 $(0 \sim 7.0 \mathrm{~cm})$ の変化率は正常者が平均 $78 \%$, 鼻アレ
ルギー患者が $102 \%$ と, 鼻腔断面積 (C-notch), 鼻腔容積 $(0.8 \sim 4.0 \mathrm{~cm})$ の変化率に比べて有意に高かった $(\mathrm{P}<$ $0.05)$.

\section{考察}

鼻疾患に打いて鼻閉の改善は重要な課題である。しか しながら，保存的あるいは外科的治療に拈いてこの鼻閉 の評価は必ずしもたやすいことではない，鼻アレルギー に拈いては自覚症状からスコア化して判断し重症度の参 考としている7). これまでは鼻腔通気度計を用いた鼻腔 抵抗の測定法が客観的評価法として用いられてきた ${ }^{8)}$. しかしながら， Naito ら²) Eccles ${ }^{3)}$ が指摘するよらに 自覚症状と鼻腔抵抗が必ずしも一致しないこと，また， 医家の立場からは前鼻鏡所見と鼻腔抵抗值の意味との関 係が不明確で戸惑らことが多いのも事実である。一方， Acoustic Rhinometry では, 坂倉ら ${ }^{9)}$ が指摘するように 音パルス反射によって前鼻孔からの距離と鼻腔断面積の 関係を距離一断面積曲線として表すことができるので視 覚的に鼻腔内の開存性を理解しやすい. そのため, 本法

表 3 血管収縮剂局所噴霧前後による鼻腔開存性の变化 （血管収縮剤噴霧後－噴霧前 $/$ 噴霧前 $\times 100 ）$

\begin{tabular}{lccc}
\hline \hline & $\begin{array}{c}\text { 正常群 }(\mathrm{N} \text { 群 }) \\
\mathrm{N}=10)\end{array}$ & $\begin{array}{c}\text { 鼻アレルギー群 }(\mathrm{A} \text { 群 }) \\
(\mathrm{N}=10)\end{array}$ & $\mathrm{N}-\mathrm{A}$ 群間 \\
\hline I . 鼻腔断面積 $(\mathrm{C}-\mathrm{notch})\left(\mathrm{cm}^{2}\right)$ & $31.3 \pm 11.9(\%)$ & $47.9 \pm 12.8$ & $\mathrm{P}<0.05$ \\
II. 鼻腔容積 $(0.8 \sim 4.0 \mathrm{~cm})\left(\mathrm{cm}^{3}\right)$ & $30.1 \pm 12.3$ & $48.3 \pm 13.1$ & $\mathrm{P}<0.05$ \\
III. 鼻腔容積 $(0 \sim 7.0 \mathrm{~cm})\left(\mathrm{cm}^{3}\right)$ & $78.4 \pm 23.0$ & $102.5 \pm 33.6$ & $\mathrm{P}<0.05$ \\
\hline I-III間 & $\mathrm{P}<0.05$ & $\mathrm{P}<0.05$ & \\
II-III間 & $\mathrm{P}<0.05$ & $\mathrm{P}<0.05$ &
\end{tabular}


が紹介されて以来, 鼻閉に対する評価への応用に向けて の研究がなされてきた. Lenders ら ${ }^{5)}$ はその曲線の特徵 から鼻腔断面積の狭くなる部位が 2 力所存在することを 報告し, I-notch, C-notch と呼称し, 前者は外側鼻軟骨 先端, 後者は下鼻甲介前下端にあたるとした。しかしな がら，その後の Acoustic Rhinometryによる定量的評 価法は, 最小鼻腔断面積, あるいは片側鼻腔全体の鼻腔 容積で表すことが注とんどである10)。注かの検討項目と しては, Roitman ら ${ }^{11)}$ は鼻孔より $0 \sim 2 \mathrm{~cm}, 2 \sim 4 \mathrm{~cm}, 4$ $\sim 6 \mathrm{~cm}, \quad 6 \sim 8 \mathrm{~cm}$ ， と鼻腔内を分けて鼻腔容積を計算し ているが，この分類も解剖学的, 臨床的に意味付けられ たものではない。これらのパラメータは, 鼻腔通気度 計にかわって鼻腔の通気性を評価しているにすぎず, Acoustic Rhinometry の特徴を生かしているとはいえな い. 一方, 音パルス反射では, 鼻腔の形状によって鼻腔 開存性が過小評価されたり過大評価されることがあり, 横山ら ${ }^{12)}$ はいくつかの断面積をもったアクリル板を並 べ，距離一断面積曲線に近似するモデルを作製し実際の 断面積とAcoustic Rhinometry による断面積とを比較 し，必ずしも実際の断面積を表していないと報告した。 したがってAcoustic Rhinometry は呼吸生理学的な意 味での鼻閉の診断には限界があるように思われる。しか しながら，得られる測定曲線は Lenders ら5)の言うょう に解剖学的に意味のある曲線であると考光られる. 私達 のエポキシパテを用いた鼻腔モデルによる検討では Cnotch の変化で鼻粘膜の腫脹, 収縮の程度を評価できる ことを報告した6)。そこで，今回は臨床応用へのステッ プとして正常者と通年性鼻アレルギー患者に血管收縮剤 を用いて鼻腔開存性の変化を観察した。

これまでにも，血管収縮剤を使用すると鼻粘膜が収縮 しAcoustic Rhinometryにより鼻腔開存性が改善する ことが確認されている. 田中ら ${ }^{13)}$ は血管収縮剤点鼻 10 分後に最小鼻腔断面積, 鼻腔容積 (鼻入口部 $7.0 \mathrm{~cm}$ ) の増加を報告して拉り，特に下鼻甲介前端付近の変化が 著明であったと述べている. しかし，後方の曲線の変化 については，詳しく言及されていない，今回の結果では 血管收縮剂噴霧後, 前鼻孔から $\mathrm{CP}$ 点までに影著な変化 が認められ, 収縮後の測定曲線は, $\mathrm{CP}$ 点を境に曲線の 変化の異なる特徴的なパターンを示した．CP 点の位置 は前鼻孔からほぼ $4 \mathrm{~cm}$ の距離にあたった．解剖学的に は中鼻甲介前端付近にあたると思われた. 曲線の特徵的 変化の原因として，音パルス反射を利用した Acoustic
Rhinometry の特性から，鼻腔前方の急激な鼻腔開存性 の変化が後方に影響した可能性があると考えられた. 又, 加瀬ら ${ }^{14)}$ は副鼻腔の影響についても指摘している。し かしながら，片田ら ${ }^{15)} は ，$ 姿勢を変化させた時，最小 鼻腔断面積よりC-notch から後方の変化が強くでたと報 告している．したがって，今回の結果より鼻アレルギー 症例に执いて CP 点が鼻粘膜の收縮の際に, 正常者に比 べてより強調されていることを考光合わせると，この $\mathrm{CP}$ 点が解剖学的にも生理学的にも意味のあるポイント であると思われた．すなわち，鼻粘膜の変化は前鼻孔と 前鼻孔から $\mathrm{CP}$ 点までの間が重要であると考学られた。 呼吸生理学的には Eccles ${ }^{16)}$ が外側鼻軟骨前端から下鼻 甲介までを鼻粘膜腫脹収縮の重要な部位とし Resistive Valve Region と定義した. このような観点と今回の結 果を組み合わせると， I-notch の頂点から C-notch の後 縁までを鼻粘膜の変動範囲とし，その鼻腔容積の変化か ら腫脹収縮を評価することが解剖学的にも生理学的にも 意味のあることと思われた。 日本人におけるI-notch の 頂点は前鼻孔より平均 $0.8 \mathrm{~cm}$ であった ${ }^{17)}$. そこで，鼻 粘膜変化を前鼻孔からの距離を $0.8 \sim 4.0 \mathrm{~cm}$ までの鼻 腔容積の変化として規定し, 検討項目として加えた.

鼻アレルギー患者の鼻粘膜は正常者に比べて腫脹して いることはAcoustic Rhinometryに扔いても Hilberg ら ${ }^{18)}$ が鼻腔断面積の検討で報告している.この原因は， 鼻粘膜の栄養血管の緊張低下あるいは血管透過性の充進 によるものと考觉られ，これは血管収縮剤を局所噴霧す ることにより鼻粘膜の収縮の程度を比較検討することで 確かめられる. 田中ら ${ }^{13}$ ) は正常者に血管收縮剂(硝酸ナ ファゾリン)を点鼻しAcoustic Rhinometryにより鼻腔 開存性の変化を経時的に測定した．その結果10分後に最 小鼻腔断面積, 鼻腔容積の増加がピークであったと報告 している. 今回， $\alpha$ 受容体に選択的に作用し，速効性で もある硝酸ナファジリンの定量局所噴霧による鼻粘膜の 変化をAcoustic Rhinometry で検討した。その結果, 収縮前に括いては鼻アレルギー患者は正常者に比べて鼻 腔開存性が有意な狭小を示したものが $(\mathrm{P}<0.05)$, 血管 収縮剂噴霧後の, 鼻腔断面積 (C-notch), 鼻腔容積 $(0.8$ $\sim 4.0 \mathrm{~cm}), \quad(0 \sim 7.0 \mathrm{~cm})$ では各々, 正常者に括いて子鼻 アレルギー患者に扒いても有意差は認められなかった。

一方, 血管収縮剂噴霧前後の変化率は鼻腔断面積, 鼻 腔容積 $(0.8 \sim 4.0 \mathrm{~cm})$ で, 正常者が注汸30\%の増加, 鼻 アレルギー患者が $48 \%$ の増加を示した。したがって，鼻 
アレルギー患者の鼻粘膜は正常者に比べて腫脹が著しい ことが解った。 これまでにも, Hilberg ら ${ }^{18)}$ は血管収縮 剂噴霧前後の鼻腔開存性を検討しているが，鼻アレル ギー患者と正常者との変化率の比較は行っていない.今 回, 正常者と鼻アレルギー患者の変化率に有意差が認め られたことより，血管収縮剤による鼻腔開存性の変化率 が鼻アレルギーの鼻粘膜の腫脹度の評価に役立つと考え られた。鼻腔全体を測定した鼻腔容積 $(0 \sim 7.0 \mathrm{~cm})$ では， 正常者も鼻アレルギ一患者も血管収縮剤による変化率は, $78 \% ， 102 \%$ と他の検討項目に比べて有意に高かったが， これを直ちに鼻腔後方の粘膜の変化が著しいと考觉るの は早計であると思われた。なぜなら，鼻腔前方の鼻粘膜 の変化が著しいと, 複雑な鼻腔構造では音パルスが放散, あるいは吸収される可能性があるからで，その結果 Acoustic Rhinometry は過大評価になると考えられ, 後 方の鼻腔開存性にはまだ検討しなければならない問題が あると思われた。

また，血管収縮剤によって鼻腔開存性が正常者と鼻ア レルギー患者でほぼ等しい結果が得られたといらことは， 収縮後の測定曲線が各々の鼻腔構造を反映したものと考 えることができ, 鼻腔開存性の基準とすることが可能と 思われた。これまでにも Grymerら ${ }^{19)}$ は Acoustic Rhinometry による安静時の鼻腔開存性の正常基準值の 検討を欧米人を対象に行っているが，個人個人により鼻 腔構造が異なること，さらには鼻粘膜は常に一定の状態 に保たれているわけではないので，正常の定義は難しい と述べている，しかしながら，血管収縮剤噴霧前後で測 定曲線の比較をすると鼻粘膜の腫脹が解剖学的にどの部 位が腫脹しているか視覚的にも定量的にも評価すること が可能である. 個々の対象について検討する場合, 鼻ア レルギー患者に対し, 抗アレルギー阂などの治療効果を 鼻粘膜とくに下鼻甲介粘膜腫脹の改善という観点で評価 する際, 血管収縮剂噴霧後の測定曲線および, 鼻腔容積 $(0.8 \sim 4.0 \mathrm{~cm})$ を一つの目標值にすることが可能であり, Acoustic Rhinometry の臨床応用の幅を増すものと考党 られた。

Kim $5^{20)}$ は, Acoustic Rhinometry の有用性につい て鼻閉を主訴とした患者に血管収縮剤を噴霧し，自覚症 状と鼻腔開存性について検討した結果, その改善度に相 関は認められず，鼻閉の診断に疑問を呈しているが，本 法の特性は鼻腔内の变化を記録し，得られた曲線を視覚 的に評価することにあると思われる．したがって，鼻腔
断面積, 鼻腔容積といった数量的な検討だけではなく， 測定曲線そのものの観察と，C-notch すなわち下鼻甲介 粘膜の腫脹の評価を, 血管収縮剤噴霧前後で比較するこ とが，鼻アレルギーの個々の症例に拉ける鼻粘膜腫脹の 程度と治療目標に有益であると考えられた。

\section{まとめ}

(1)血管収縮斉の局所噴霧により鼻粘膜の収縮をAcoustic Rhinometryにより観察した.

(2)血管収縮剤噴霧により測定曲線は前鼻孔より 4.0 $\mathrm{cm}$ 前後で特徵的な変化を示した.

(3)鼻アレルギーの鼻腔開存性は正常成人に比べて血管 収縮剤噴霧前において有意に狭小化していた。

(4)血管収縮剂噴霧後には鼻アレルギー患者と正常成人 の鼻腔開存性に有意差は認められなかった.

(5)Acoustic Rhinometry は鼻アレルギーの鼻粘膜腫脹 の評価に有益であると考えられた。

\section{参考文献}

1 ) 江田昭英 : 序論. 抗アレルギー薬の作用機序と効果(信太 隆夫, 江田昭英編). 7 13頁, メディカルトリビューン, 東京, 1992.

2 ) Naito K, Cole P, Chaban R, et al : Nasal resistance, sensation of obstruction and rhinoscopic finding compared. Am J Rhinol 2 : 65 69, 1988.

3 ) Eccles R : Nasal airway resistance and nasal sensation of air flow. Rhinology Suppl $14:$ 86 90, 1992.

4 ) Hilberg O, Jackson A, Swift D, et al : Acoustic rhinometry ; evaluation of nasal cavity geometry by acoustic reflections. J Appl Physiol 66 : 295 303, 1989.

5 ) Lenders H and Pirsig W : Diagnostic value of acoustic rhinometry; patients with allergic and vasomotor rhinitis compared with normal controls. Rhinology $28: 5 \sim 16$, 1990.

6 ）大木幹文, 白井信郎：鼻アレルギーに括ける鼻閉の評価と Acoustic rhinometry の役割. 日鼻誌 $36: 152,1997$.

7 ) 牧野荘平 監修: 鼻アレルギー(含 花粉症)の診断と治療. ライフサイェンス・メディカ, 東京, 1995.

8 ）戸川 清: 鼻呼吸障害 一その病態生理と臨床一. 第83回 日本耳鼻咽喉科学会総会, 宿題報告. 盛岡, 1982 .

9 ）坂倉康夫, 宮原幸則 : Acoustic Rhinometry. 日耳鼻専門 医通信 $39: 14 \sim 15,1994$.

10) Grymer LF, Hilberg $O$ and Pedersen OF : Prediction of nasal obstruction based on clinical examination and acoustic rhinometry. Rhinology $35: 53 \sim 57,1997$. 
11) Roitman R, Cole P, Chapnik J, et al : Acoustic rhinometry in the evaluation of nasal obstruction. Laryngoscope $105: 275 \sim 281,1995$.

12）横山貴康, 谷田光弘, 野中 聡, 他 : Acoustic Rhinometry と Rhinomanometry 測定值との関係. 日鼻誌 35 : $357 \sim 360,1996$

13）田中利善, 沖田 渉, 加瀬康弘 : Acoustic Rhinometry に よる血管収縮剤の評価.日耳鼻 $97: 207 〜 212,1994$.

14）加瀬康弘，市村恵一，飯沼壽孝：副鼻腔検査法としての Acoustic rhinometry の応用一実験的研究一. 日耳鼻 96 : $626 \sim 631,1993$.

15）片田彰博, 坂田文, 榎本啓一, 他 : Acoustic Rhinometry を用いた体位変換誘発の鼻腔変化の解析. 日鼻誌 $35:$ 135 140, 1997.

16) Eccles $R$ : Rhinomanometry and nasal challenge. Mackay IS of Otolaryngology-Rhinology 5th ed (ed by Bull TR). pp 41, Butterworth, London, 1987.

17）大木幹文，臼井信郎：Acoustic rhinometry からみた鼻弁
の付近. JOHNS $10: 834 \sim 837,1987$.

18) Hilberg O, Grymer LF, Pedersen OF, et al : Turbinate hypertrophy; evaluation of the nasal cavity by acoustic rhinometry. Arch Otolaryngol Head Neck Surg 116 : 283 $\sim 289,1990$.

19) Grymer LF, Hilberg O and Pedersen OF : Acoustic rhinometry; values from adults with subjective normal nasal patency. Rhinology $29: 35 \sim 47,1991$.

20) Kim CS, Moon BK, Jung DH, et al : Corrrelation between nasal obstruction symptoms and objective parameters of acoustic rhinometry and rhinomanometry. Auris Nasus Larynx $25:$ 45 48, 1998.

$$
\left.\begin{array}{l}
\text { 原稿受付 : 平成 } 10 \text { 年 } 4 \text { 月 } 1 \text { 日 } \\
\text { 原稿採択 : 平成 } 10 \text { 年 } 5 \text { 月 } 14 \text { 日 } \\
\text { 別刷請求先 : 大不幹文 } \\
\text { 干153- } 8515 \text { 東京都目黒区大橋2-17-6 } \\
\text { 東邦大学医学部耳鼻咽喉科学第 } 2 \text { 講座 }
\end{array}\right)
$$

